\title{
EDUKASI MENINGKATKAN PENGETAHUAN DAN SIKAP IBU DALAM PENCEGAHAN KEJANG DEMAM BERULANG
}

\author{
Jayanti Dwi Puspitasari ${ }^{1,2, *}$ Nani Nurhaeni ${ }^{3}$, Allenidekania ${ }^{3}$ \\ ${ }^{1}$ Program Studi Magister Fakultas Ilmu Keperawatan Universitas Indonesia, Depok, Jawa Barat-16424 \\ ${ }^{2}$ RSUD Dr. R. Soedjati Soemodiardjo, Purwodadi, Grobogan, Jawa Tengah, Indonesia \\ ${ }^{3}$ Fakultas Ilmu Keperawatan Universitas Indonesia, Depok, Jawa Barat-16424 \\ *E-mail: jayantipuspitasari@gmail.com
}

\begin{abstract}
ABSTRAK
Latar Belakang: Kejang demam yang terjadi berulang akan mengakibatkan efek yang buruk bagi anak, terutama untuk kecerdasan dan perkembangan otak. Salah satu cara untuk mencegah kejang demam berulang adalah dengan memberikan edukasi kesehatan kepada ibu. Edukasi kesehatan dapat meningkatkan pengetahuan ibu, sehingga sikap ibu akan berubah kearah positif. Tujuan: untuk mengetahui pengaruh edukasi kesehatan terhadap pengetahuan dan sikap ibu dalam pencegahan kejang demam berulang. Metode: Desain penelitian ini adalah Quasi Experiment dengan teknik pre test and post test nonequevalent control group pada 58 responden (kelompok intervensi=29 dan kelompok kontrol=29). Instrumen yang digunakan dalam penelitian ini adalah kuesioner A, B, C dan media audiovisual. Responden adalah ibu yang memiliki balita pernah mengalami kejang demam dan pernah dirawat di rumah sakit. Kelompok intervensi diberikan edukasi kesehatan tentang pencegahan kejang demam berulang dengan media video, sedangkan kelompok kontrol tidak diberikan intervensi. Analisis yang digunakan dalam penelitian ini adalah analisis bivariat dengan uji paired t-test dan independent t-test dan multivariate dengan MANCOVA. Hasil: ada pengaruh edukasi kesehatan terhadap pengetahuan $(p=0,001)$ dan sikap $(p=0,001)$. Kesimpulan: Edukasi dapat dimasukkan ke dalam rencana asuhan keperawatan ketika anak pertama kali dirawat di rumah sakit karena kejang demam, karena terbukti dapat meningkatkan pengetahuan ibu sehingga ibu dapat mengambil sikap yang positif untuk pencegahan terjadinya kejang demam berulang.
\end{abstract}

Kata kunci: edukasi kesehatan, pengetahuan, sikap, kejang, demam The Effect of Health Education on Knowledge and Attitude of Mothers in Preventing the
Recurrent Febrile Seizures

ABSTRACT

The Recurrent Febrile Seizures (RFS) could affect the children intelligence and their brain development. Health education is one of the ways in order to prevent the RFS. By providing health education among mothers, it might increase their knowledge and could lead to a positive attitude in preventing the RFS. Aim: This study was aimed at investigating the effect of health education on knowledge and attitude of mothers in preventing the RFS among hospitalized children. Method: This was a quasi-experimental study with pre-and post-test nonequivalent control group with total sample was 58 respondents (intervention group, $n=29$, and control group, $n=29$ ). The instruments used in this study were questionnaire A, B, C and audiovisual media. Respondents in this determination are mothers who have children who have experienced febrile seizures and have been hospitalized. The video guidelines on RFS prevention was performed in the intervention group, while there was no intervention performed in the control group.Data was analysed with univariate (paired t-test and unpaired t-test) and multivariate with MANCOVA. Result: There was a significant effect of health education on knowledge ( $p=0.001)$, and attitude $(p=0.001)$. Conclusion: Health education should be included in the nursing care plan when the children with RFS were admitted to the hospital.

Keywords: Health education, knowledge, attitude, febrile, seizures. 


\section{PENDAHULUAN}

Kejang demam adalah kejang yang terjadi akibat adanya kenaikan suhu lebih dari $38^{\circ} \mathrm{C}$ (Sadleir \& Scheffer, 2007). Sedangkan The International League Against Epilepsy (ILAE) dalam Patel, dkk (2015) mendefinisikan kejang demam sebagai kejang yang terjadi pada usia di atas 1 bulan yang berkaitan dengan demam bukan disebabkan oleh infeksi dari sistem saraf pusat, tanpa kejang neonatal atau kejang tak beralasan sebelumnya. Kejang demam dapat mengakibatkan gangguan tingkah laku, penurunan intelegensi dan pencapaian tingkat akademik yang menurun. Beberapa hasil penelitian mengatakan penurunan intelegensi berbeda pada setiap anak (Kalalang, Masloman, \& Manoppo, 2016). Patel, dkk (2015) mengatakan anak yang mengalami kejang demam berulang dan komplek memengaruhi kecerdasan, perkembangan bahasa dan gangguan memori. Sedangkan Najimi, dkk (2013) menjelaskan komplikasi dari kejang demam meliputi: perkembangan saraf yang tertunda $(20 \%)$, cacat neurologi $(10 \%)$ dan ketidakmampuan belajar (5\%).

Kejang demam merupakan salah satu masalah yang banyak terjadi hampir di seluruh dunia. Hampir 10\% anakanak pernah mengalami kejang demam (Soundari, Kokilavani \& Kumar, 2014). Insiden kejang demam di beberapa negara berbeda-beda. Insiden di Amerika dan Eropa Barat sekitar 2-5\%, Sedangkan di Asia seperti India berkisar 5-10\%, Jepang berkisar 6-9\%. Prevalensi tertinggi di negara Guam yaitu 14\% (Paul, Blaikley, \& Chinthapalli, 2012). Berdasarkan hasil Survey Demografi Kesehatan Indonesia (SDKI) tahun 2007, pada tahun 2005-2006 angka kejang demam di Indonesia mencapai 2-4\%, di propinsi Jawa Tengah mencapai 2-5\%. Sedangkan di RSUD Grobogan angka kejang demam pada tahun 2016 sebanyak
74 orang dan pada tahun 2017 sebanyak 130 orang meningkat sebesar $75,68 \%$.

Deliana (2002) menjelaskan tujuan perawatan kejang demam yaitu mencegah kejang demam berulang. Mencegah kejang demam berulang dapat dilakukan dengan cara memberikan pendidikan kesehatan pada orang tua. Pemberian pendidikan kesehatan pada ibu merupakan bagian dari prinsip perawatan yang berfokus pada keluarga serta merupakan peran perawat profesional sebagai pemberi penyuluhan kesehatan (Hockenberry \& Wilson, 2009).

Menurut Kizilay, dkk (2017), memberikan informasi kepada orang tua tentang efek kejang demam itu sangat penting. Ketidaktahuan orang tua akan menimbulkan kecemasan. Ketika cemas orang tua cenderung protektif sehingga dapat menghambat perkembangan anak. Sedangkan Najimi, dkk (2013) mengatakan bahwa pendidikan kesehatan terbukti efektif dalam meningkatkan pengetahuan, sikap dan praktek ibu tentang pencegahan kejang demam pada anak.

Najimi, dkk (2013) mengatakan bahwa pendidikan kesehatan terbukti efektif dalam meningkatkan pengetahuan, sikap dan praktek ibu tentang pencegahan kejang demam pada anak. Sejalan dengan penelitian Soundari, Kokilavani, dan Kumar (2014) yang menjelaskan bahwa orang tua yang telah diberikan pendidikan kesehatan, akan mengalami peningkatan pengetahuan dan sikap dalam merawat anak dengan kejang.

Notoatmodjo (2005) mengatakan penggunaan media bukanlah sesuatu yang utama dalam promosi kesehatan, akan tetapi promosi kesehatan tidak dapat dipisahkan dari penggunaan media. Sejalan dengan Arsyad (2013) yang mengatakan pemilihan media yang tepat pada pendidikan kesehatan menjadi penting karena media berperan sebagai perantara dalam memperjelas dan 
mengurangi kesalahan transfer informasi.

Notoatmodjo (2012) mengatakan beberapa penelitian para ahli menyebutkan bahwa indera penglihatan (mata) paling besar menyampaikan pengetahuan ke otak, yaitu $75 \%-87 \%$. Pengetahuan yang disalurkan oleh indera yang lain hanya 13\%-25\%. Dengan demikian apabila dikombinasikan, maka pengetahuan yang diserap akan semakin banyak. Sejalan dengan Penelitan Lenzowski, dkk (2017) yang mengemukakan bahwa media audiovisual lebih disukai karena dilengkapi dengan gambar sehingga responden bisa tahu dan faham dengan jelas.

Berdasarkan studi lapangan yang dilakukan di beberapa Rumah Sakit di Kabupaten Grobogan didapatkan hasil angka kejang demam di RSUD Grobogan paling tinggi yaitu 130 anak. Hasil wawancara yang dilakukan pada 4 orang tua yang anaknya sedang dirawat karena kejang demam, didapatkan 3 orang tua tidak memiliki pengetahuan dan sikap yang cukup tentang kejang demam terutama tentang bagaimana cara mencegah kejang demam berulang. Paul, Rogers dan Wilkinson (2015) mengatakan sepertiga anak-anak (30\%) akan mengalami kejang demam berulang.

Dari data di atas dapat disimpulkan bahwa edukasi diperlukan untuk meningkatkan pengetahuan dan sikap ibu agar kejang demam tidak berulang. Edukasi kesehatan dengan menggunakan media audiovisual juga belum pernah dilakukan. Hal ini membuat peneliti ingin menerapkan sistem edukasi yang berbeda dan mendukung tugas perawat sebagai care giver dan tujuan akhirnya untuk mengurangi angka kejadian kejang demam berulang. Tujuan penelitian ini adalah untuk mengetahui pengaruh edukasi terhadap peningkatan pengetahuan dan sikap ibu dalam pencegahan kejang demam berulang.

\section{METODE}

Penelitian ini merupakan penelitian kuantitatif, menggunakan desain kuasi eksperimen dengan teknik pre test and post test nonequivalent control group untuk membandingkan tindakan yang dilakukan sebelum dan sesudah intervensi. Teknik pengambilan sampel dengan consecutive sampling sebanyak 58 responden, dibagi menjadi 29 responden pada kelompok kontrol dan 29 responden pada kelompok intervensi. Penelitian ini di suatu komunitas di wilayah Kabupaten Grobogan. Penelitian ini dilakukan pada bulan April sampai Mei 2018.

Peneliti memilih calon responden sesuai kriteria inklusi dan eksklusi. Kriteria iklusi pada penelitian ini ada ibu yang memiliki balita pernah mengalami kejang demam dan pernah dirawat di rumah sakit, ibu dapat berkomunikasi dengan baik. Sedangkan kriteria eksklusi ibu yang sedang sakit dan dirawat di Rumah Sakit, anak yang mengalami kejang demam yang disebabkan infeksi yang berhubungan dengan sitem saraf pusat. Pada tahap pertama peneliti terlebih dahulu mengumpulkan responden kelompok kontrol sampai jumlahnya terpenuhi. Responden yang masuk kriteria inklusi diberikan penjelasan tentang tujuan, manfaat serta risiko penelitian kemudian jika bersedia diminta persetujuannya untuk berpartisipasi dalam penelitian dan menandatangani surat persetujuan.

Pemberian edukasi pada penelitian ini dilakukan oleh peneliti atau asisten peneliti. Pemberian edukasi diberikan sendiri-sendiri pada setiap responden. Pembuatan video diawali dengan pembuatan konsep materi dengan merujuk pada buku keperawatan anak dan jurnal terkait. Setelah konsep selesai, lalu melakukan konsul kepada pakar. Setelah materi disetujui selanjutnya dilakukan pembuatan video. 
Instrumen yang digunakan untuk mengukur pengetahuan ibu adalah kuesioner B yang terdiri dari 27 pertanyaan. Sistem skoring yang digunakan yaitu diberikan skor 1 jika jawaban benar dan skor 0 jika jawaban salah. Sedangkan instrumen yang digunakan untuk mengukur sikap ibu adalah kuesioner $\mathrm{C}$ yang terdiri dari 22 pernyataan, 9 pernyataan positif dan 13 pernyataan negatif. Kedua instrumen telah dilakukan uji validitas dan reliabilitas pada 30 ibu yang mempunyai balita yang anaknya pertama kali dirawat di rumah sakit karena kejang demam.

Hasil uji validitas kuesioner pengetahuan ada 2 pertanyaan yang tidak valid sehingga pertanyaan menjadi 20 pertanyaan dengan $r$ per item antara 0,406 sampai 0,818, sedangkan pada kuesioner sikap ada 2 pertanyaan yang tidak valid sehingga menjadi 20 pernyataan dengan $r$ per item 0,428 sampai 0,833 . Hasil uji reliabilitas kuesioner pengetahuan didapatkan nilai Cronbach's alpha 0,924 sehingga kuesioner pengetahuan dikatakan reliabel. Sedangkan hasil uji kuesioner sikap didapatkan nilai Cronbach's alpha 0,918 sehingga kuesioner sikap dikatakan reliabel.

Tahap selanjutnya melakukan pre test pada kelompok kontrol untuk mengetahui pengetahuan dan sikap ibu dalam penanganan kejang demam berulang dengan menggunakan kuesioner. Post test pada kelompok kontrol dilakukan pada hari ke7. Setelah itu kelompok kontrol diberikan edukasi pencegahan kejang demam berulang (video) berisi pengertian kejang demam, penyebab tanda gejala, faktor resiko, komplikasi, penatalaksanana dan perawatan serta pencegahan kejang demam berulang. Setelah pengumpulan responden kelompok kontrol selesai, selanjutkan mengumpulkan responden kelompok intervensi.

Pada kelompok intervensi dilakukan pre test utuk mengetahui pengetahuan dan sikap ibu dalam penanganan kejang demam berulang menggunakan kuesioner. Setelah itu diberikan edukasi menggunakan media video selama 30 menit tentang faktor resiko, komplikasi, penatalaksanaan dan perawatan serta pencegahan kejang demam berulang. Pada hari ke-7 setelah pemberian edukasi diukur kembali pengetahuan dan sikap responden dalam pencegahan kejang demam berulang.

Data hasil pre test dan post test kedua kelompok diolah dan dianalisis. Analisis data pada penelitian ini menggunakan analisis univariat, bivariat dan dan multivariat. Analisis univariat untuk menjelaskan dan mendiskripsikan karakteristik setiap variabel penelitian. Analisis bivariat yang digunakan adalah analisis variabel independen (paired t-test), analisis variabel independen dan dependen (independent t-test). Analisis multivariat yang digunakan adalah uji MANCOVA. Penelitian ini telah mendapatkan ijin etik dari komite etik Fakultas IImu Keperawatan Universitas Indonesia dengan No.107/UN2.F12.D/HKP.02.04/2018. 


\section{HASIL}

Tabel 1. Distribusi Frekuensi Responden Berdasarkan Pendidikan, Penghasilan, Keterpaparan Informasi, Usia anak dan Jenis Kelamin di RSUD Grobogan April-Mei 2018 ( $n=58)$

\begin{tabular}{|c|c|c|c|c|c|c|c|}
\hline \multirow[t]{2}{*}{ Variabel } & \multicolumn{2}{|c|}{$\begin{array}{l}\text { Intervensi } \\
(n=29)\end{array}$} & \multicolumn{2}{|c|}{$\begin{array}{l}\text { Kontrol } \\
(n=29)\end{array}$} & \multicolumn{2}{|c|}{ Total } & \multirow[t]{2}{*}{$p$ value } \\
\hline & $\mathbf{n}$ & $\%$ & $\mathrm{n}$ & $\%$ & $\mathrm{n}$ & $\%$ & \\
\hline \multicolumn{8}{|l|}{ Karakteristik Ibu } \\
\hline \multicolumn{8}{|l|}{ Pendidikan } \\
\hline Pendidikan Dasar & 21 & $72,4 \%$ & 20 & $69,0 \%$ & 41 & $70,7 \%$ & \\
\hline $\begin{array}{l}\text { Pendidikan } \\
\text { Menengah }\end{array}$ & 5 & $17,2 \%$ & 7 & $24,1 \%$ & 12 & $20,7 \%$ & 0,844 \\
\hline Pendidikan Tinggi & 3 & $10,3 \%$ & 2 & $6,9 \%$ & 5 & $8,6 \%$ & \\
\hline Total & 29 & $100 \%$ & 29 & $100 \%$ & 58 & $100 \%$ & \\
\hline \multicolumn{8}{|l|}{ Penghasilan } \\
\hline$<1,6$ juta & 16 & $55,2 \%$ & 23 & $79,3 \%$ & 39 & $67,2 \%$ & 0,64 \\
\hline$\geq 1,6$ juta & 13 & $44,8 \%$ & 6 & $20,7 \%$ & 19 & $32,8 \%$ & \\
\hline Total & 29 & $100 \%$ & 29 & $100 \%$ & 58 & $100 \%$ & \\
\hline \multicolumn{8}{|c|}{ Keterpaparan Informasi } \\
\hline Tidak Pernah & 16 & $55,2 \%$ & 15 & $51,7 \%$ & 31 & $53,4 \%$ & 0,681 \\
\hline Pernah & 13 & $44,8 \%$ & 14 & $48,3 \%$ & 27 & $46,6 \%$ & \\
\hline Total & 29 & $100 \%$ & 29 & $100 \%$ & 58 & $100 \%$ & \\
\hline \multicolumn{8}{|l|}{ Karakteristik Anak } \\
\hline $\begin{array}{l}\text { Usia } \\
\leq 60 \text { bulan } \\
>60 \text { bulan }\end{array}$ & $\begin{array}{c}29 \\
0\end{array}$ & $\begin{array}{c}100 \% \\
0 \%\end{array}$ & $\begin{array}{c}29 \\
0\end{array}$ & $\begin{array}{c}100 \% \\
0 \%\end{array}$ & $\begin{array}{c}58 \\
0\end{array}$ & $\begin{array}{c}100 \% \\
0 \%\end{array}$ & 1,000 \\
\hline Total & 29 & $100 \%$ & 29 & $100 \%$ & 58 & $100 \%$ & \\
\hline \multicolumn{8}{|l|}{ Jenis Kelamin } \\
\hline Laki-laki & 16 & $55,2 \%$ & 14 & $48,3 \%$ & 30 & $51,7 \%$ & 0,397 \\
\hline Perempuan & 13 & $44,8 \%$ & 15 & $51,7 \%$ & 28 & $48,3 \%$ & \\
\hline Total & 29 & $100 \%$ & 29 & $100 \%$ & 58 & $100 \%$ & \\
\hline
\end{tabular}


Tabel 1 menunjukkan bahwa mayoritas ibu berpendidikan dasar, mempunyai penghasilan <Rp.1.600.000,- dan belum pernah terpapar informasi tentang kejang demam. Kejang demam lebih banyak dialami oleh anak laki-laki.

Tabel 2. Rata-Rata Perbedaan Skor Pengetahuan dan Sikap Ibu dalam Pencegahan kejang demam Berulang Sebelum dan Setelah diberikan Edukasi Kesehatan pada kelompok Kontrol dan Intervensi di RSUD Grobogan April-Mei 2018 (n=58)

\begin{tabular}{|c|c|c|c|c|c|}
\hline Kelompok & Variabel & Pengukuran & Mean & SD & p value \\
\hline \multirow[t]{4}{*}{ Kontrol } & Pengetahuan & Sebelum & 56,28 & 7,923 & 0,057 \\
\hline & & Sesudah & 57,66 & 7,598 & \\
\hline & Sikap & Sebelum & 67,52 & 6,300 & 0,804 \\
\hline & & Sesudah & 72,62 & 6,085 & \\
\hline \multirow[t]{4}{*}{ Intervensi } & Pengetahuan & Sebelum & 58,62 & 8,300 & $<0,001^{*}$ \\
\hline & & Sesudah & 71,45 & 8,798 & \\
\hline & Sikap & Sebelum & 67,2 & 5,209 & $<0,001^{*}$ \\
\hline & & Sesudah & 75,76 & 5,104 & \\
\hline
\end{tabular}

Keterangan: *bermakna $\alpha<0,05$

Tabel 2 menunjukkan perbedaan rerata skor pengetahuan dan sikap ibu sebelum dan sesudah diberikan edukasi pada kelompok kontrol dan kelompok intervensi. Rerata pengetahuan dan sikap ibu sebelum dan sesudah edukasi pada kelompok kontrol tidak ada perbedaan dengan $p$ value 0,057 dan 0,804 . Sedangkan rerata pengetahuan dan sikap ibu sebelum dan sesudah edukasi pada kelompok intervensi menunjukkan adanya perbedaan dengan $p$ value $<0,001$. 
Tabel 3. Rata-rata Perbedaan Skor Pengetahuan dan Sikap Ibu dalam

Pencegahan Kejang Demam Berulang Setelah diberikan Edukasi

Kesehatan pada Kelompok Intervensi dan Kelompok Kontrol di RSUD Grobogan April-Mei 2018 ( $n=58)$

\begin{tabular}{llccccc}
\hline Variabel & Kelompok & $\mathbf{n}$ & Mean & SD & p value & $\begin{array}{c}\text { Selisih } \\
\text { mean }\end{array}$ \\
\hline Pengetahuan & Intervensi & 29 & 71,45 & 8,798 & $0,001^{*}$ & 13,85 \\
& Kontrol & 29 & 57,66 & 7,598 & & \\
Sikap & Intervensi & 29 & 75,76 & 5,104 & $0,001^{*}$ & 8,14 \\
& Kontrol & 29 & 67,62 & 6,085 & & \\
\hline
\end{tabular}

Keterangan: *bermakna $\alpha<0,05$

Tabel 3 menunjukkan perbedaan rerata pengetahuan ibu setelah pemberian edukasi pada kelompok intervensi dan kelompok kontrol dengan beda mean 13,85 dan nilai $p=0,001 \quad(p<0,05)$. Hal ini membuktikan bahwa kelompok yang diberikan edukasi kesehatan pengetahuannya lebih meningkat dibandingkan dengan kelompok yang tidak diberikan edukasi kesehatan. Beda mean sikap setelah pemberian edukasi pada kelompok intervensi dan kelompok kontrol adalah 8,14 dengan nilai $p=0,001$. Hal ini menunjukkan bahwa kelompok yang diberikan edukasi mempunyai peningkatan sikap yang lebih baik dibandingkan dengan kelompok kontrol. 
Tabel 4. Analisis Mancova Efektivitas Pemberian Edukasi Terhadap Pengetahuan dan Sikap Ibu dengan Variabel Perancu dalam Pencegahan Kejang Demam $(n=58)$

\begin{tabular}{|c|c|c|c|c|}
\hline Source & $\begin{array}{l}\text { Dependent } \\
\text { Variabel }\end{array}$ & f & Sig. & $\begin{array}{c}\text { Partial Eta } \\
\text { Squared }\end{array}$ \\
\hline \multirow[t]{2}{*}{ Corrected Model } & Sikap & 11,06 & 0,000 & 0,747 \\
\hline & Pengetahuan & 10,49 & 0,000 & 0,737 \\
\hline \multirow[t]{2}{*}{ Intercept } & Sikap & 2803,90 & 0,000 & 0,984 \\
\hline & Pengetahuan & 1007,88 & 0,000 & 0,957 \\
\hline \multirow[t]{2}{*}{ Usia Ibu } & Sikap & 2,29 & 0,137 & 0,048 \\
\hline & Pengetahuan & 0,14 & 0,703 & 0,003 \\
\hline \multirow[t]{2}{*}{ Tingkat Pendidikan } & Sikap & 10,09 & 0,001 & 0,310 \\
\hline & Pengetahuan & 11,65 & 0,001 & 0,341 \\
\hline \multirow[t]{2}{*}{ Penghasilan } & Sikap & 1,40 & 0,242 & 0,030 \\
\hline & Pengetahuan & 2,65 & 0,110 & 0,056 \\
\hline \multirow{2}{*}{$\begin{array}{l}\text { Keterpaparan } \\
\text { Informasi }\end{array}$} & Sikap & 5,62 & 0,022 & 0,111 \\
\hline & Pengetahuan & 0,001 & 0,110 & 0,000 \\
\hline \multirow{2}{*}{$\begin{array}{l}\text { Riwayat Kejang } \\
\text { Anak }\end{array}$} & Sikap & 1,43 & 0,245 & 0,087 \\
\hline & Pengetahuan & 0,78 & 0,511 & 0,049 \\
\hline \multirow{2}{*}{$\begin{array}{l}\text { Riwayat Dirawat } \\
\text { karena Kejang }\end{array}$} & Sikap & 0,59 & 0,625 & 0,038 \\
\hline & Pengetahuan & 0,23 & 0,870 & 0,016 \\
\hline \multirow[t]{2}{*}{ Jenis kelamin } & Sikap & 0,533 & 0,469 & 0,152 \\
\hline & Pengetahuan & 1,335 & 0,254 & 0,084 \\
\hline \multirow[t]{2}{*}{ Usia Anak } & Sikap & 0,234 & 0,631 & 0,023 \\
\hline & Pengetahuan & 0,007 & 0,936 & 0,054 \\
\hline \multirow{2}{*}{$\begin{array}{l}\text { Pemberian } \\
\text { Edukasi }\end{array}$} & Sikap & 41,07 & 0,001 & 0,984 \\
\hline & Pengetahuan & 46,18 & 0,001 & 0,957 \\
\hline
\end{tabular}


Hasil analisis pada Tabel 4 menunjukkan bahwa terdapat hubungan yang signifikan antara pemberian edukasi dengan pengetahuan dan sikap ibu dalam pencegahan kejang demam berulang setelah dikontrol oleh variabel perancu dengan nilai $p=0,001(p<0,05)$. Hasil ini menunjukkan bahwa variabel perancu tidak memengaruhi pengetahuan. Namun ada dua variabel perancu yang memengaruhi walaupun telah dikontrol yaitu tingkat pendidikan dan keterpaparan informasi.

\section{DISKUSI}

Gambaran umum karakteristik anak yang diteliti pada penelitian ini adalah umur anak, jenis kelamin, riwayat anak kejang dan riwayat anak dirawat karena kejang. Dari segi usia penelitian ini menunjukkan bahwa anak yang mengalami kejang demam terbanyak berusia $<32$ bulan. Hal ini sesuai oleh teori yang dijelaskan oleh Kyle \& Carman (2017) bahwa usia kurang dari 2 tahun perkembangan otak anak belum matang, sehingga anak lebih rentan mengalami kejang.

Menurut hasil penelitian Patel, dkk (2015), anak yang berusia di bawah 2 tahun lebih banyak yang mengalami kejang demam dibandingkan anak yang berusia lebih dari dua tahun. Sejalan dengan penelitian Najimi, dkk (2013) yang menjelaskan bahwa kejang demam terbanyak terjadi pada usia kurang dari 2 tahun. Dari beberapa hasil penelitian di atas dapat disimpulkan bahwa semakin muda usia anak, akan semakin berisiko mengalami kejang demam.

Penelitian ini menemukan kejang demam lebih banyak terjadi pada anak lakilaki. Penelitian yang dilakukan Eskandarifar, dkk (2017) juga menemukan bahwa anak laki-laki lebih banyak mengalami kejang demam dibandingkan dengan anak perempuan. Hasil ini sesuai hasil penelitian Onji, dkk (2009) yang menemukan bahwa ada hubungan yang bermakna antara jenis kelamin dengan kejang pada anak $(p=0,024$; $p<0,05)$.

Karakteristik ibu yang dikaji dalam penelitian adalah usia ibu, pendidikan dan penghasilan keluarga dan keterpaparan informasi. Hasil penelitian menunjukkan bahwa mayoritas ibu berusia 31 tahun. Menurut Wawan \& Dewi (2010), usia tiga puluhan adalah usia yang dianggap matang untuk menerima dan memutuskan suatu tindakan yang tepat. Hal ini sejalan dengan penelitian Santoso \& Ismail (2009) yang mengatakan bahwa semakin bertambahnya umur seseorang maka kematangan dalam berpikir semakin baik, sehingga akan cepat dalam pengambilan suatu keputusan misalnya ketika anak demam akan segera diatasi agar tidak terjadi kejang demam berulang.

Hasil penelitian ini menunjukkan bahwa mayoritas sebagian besar ibu berpendidikan dasar, yaitu 41 responden (70,7\%). Menurut Maryati \& Septikasari (2009), pendidikan seseorang secara tidak langsung dapat berpengaruh terhadap kesehatan. Tingkat pendidikan dasar termasuk level yang belum mampu bersikap secara cepat dan tanggap untuk mencari pertolongan dan pergi ke fasilitas kesehatan. Tingkat pendidikan perlu diidentifikasi karena beberapa penelitian menunjukkan bahwa tingkat pendidikan berpengaruh secara signifikan terhadap tingkat pengetahuan dan sikap orang tua. Hal ini sesuai dengan hasil penelitian Hanafi, dkk (2014) yang menjelaskan bahwa ada hubungan yang bermakna antara pendidikan ibu tehadap peningkatan pengetahuan, sikap dan ketrampilan ibu dalam pemberian ASl eksklusif.

Hasil penelitian menunjukkan bahwa mayoritas keluarga berpenghasilan kurang dari UMR yaitu 39 responden $(67,2 \%)$. Guttmacher (2005) menjelaskan bahwa penghasilan dapat mengukur masalah 
kesehatan keluarga. Penghasilan perlu diperhatikan karena pada level penghasilan lebih tinggi orang tua mampu mengakses informasi dan fasilitas kesehatan yang lebih baik. Sesuai dengan penjelasan Wawan \& Dewi (2010) yaitu semakin tinggi status ekonomi seseorang maka fasilitas akan lebih mudah didapat termasuk fasilitas kesehatan.

Hasil penelitian ini menunjukkan bahwa lebih dari setengah responden yaitu 31 orang $(54,4 \%)$ tidak pernah mendapatkan informasi. Menurut Priyoto (2014) salah satu faktor yang dapat memengaruhi sikap seseorang adalah pengalaman. Menurut penelitian Legg \& Newton (2016), orang tua yang mempunyai pengalaman pernah mendapatkan informasi tentang kejang dapat mengurangi faktor risiko terjadinya cedera saat anak mengalami kejang demam. Orang tua tidak takut dan panik saat menangani anak kejang sehingga penanganan pertama anak kejang bisa dilakukan dengan baik.

Pada hasil penelitian ini juga terdapat perbedaan secara bermakna pengetahuan ibu pada kedua kelompok setelah pemberian edukasi dengan nilai $p=0,001 ;(p<0,05)$. Hal ini menunjukkan bahwa pemberian edukasi kesehatan mempunyai dampak dalam meningkatkan pengetahuan orang tua. Maulana (2009) menjelaskan bahwa semakin sering seseorang mendapatkan informasi maka pengetahuan akan semakin meningkat. Peningkatan pengetahuan orang tua akan memengaruhi sikap orang tua kearah yang lebih baik atau positif.

Hasil penelitian Eze, dkk (2015) tentang efek edukasi kesehatan terhadap pengetahuan, sikap dan pertolongan pertama pada epilepsi menunjukkan bahwa setelah diberikan pendidikan kesehatan terdapat perubahan pengetahuan secara bermakna. Terdapat peningkatan pengetahuan sebesar $25,9 \%$ setelah intervensi, dari pengetahuan yang kurang dan cukup menjadi pengetahauan yang baik, dengan nilai statistik $p<0,05$. Hal ini menunjukkan bahwa pendidikan kesehatan secara bermakna dapat merubah pengetahuan seseorang.

Guguen, dkk (2010) menjelaskan tujuan memberikan informasi kesehatan kepada seseorang adalah untuk memotivasi agar bergaya hidup ke arah yang positif. Hasil dari penelitian ini menunjukkan adanya peningkatan pengetahuan orang tua mengenai demam dan penanganan demam setelah orang tua mendapatkan informasi. Arsyad (2013) mengatakan informasi adalah salah satu sumber kekuatan keluarga dalam menjaga kesehatan anaknya, maka informasi yang kita berikan harus jelas, akurat dan relevan. Untuk itu pemilihan media yang tepat pada pendidikan kesehatan menjadi penting.

Hasil penelitian Lee, Kim \& Min (2017) menunjukkan bahwa pemberian informasi dengan menggunakan smartphone terbukti efektif dalam meningkatkan pengetahuan dan kepecayaan diri orang tua dibandingkan dengan menggunakan media kertas. Hal ini sesuai Penelitan Lenzowski, dkk (2017) yang mengemukakan bahwa media audiovisual lebih disukai karena dilengkapi dengan gambar atau foto yang seolah nyata membuat responden lebih mudah faham.

Hasil analisis multivariat dalam penelitian ini menunjukkan ada pengaruh yang signifikan antara pemberian edukasi dengan pengetahuan ibu $(p<0,001)$ setelah dikontrol oleh variabel usia ibu, tingkat pendidikan, penghasilan, keterpaparan informasi, riwayat anak dirawat dan riwayat anak dirawat karena kejang. Namun ditemukan variabel perancu yang tetap memengaruhi pengetahuan walaupun telah dikontrol yaitu tingkat pendidikan.

Tingkat pendidikan berpengaruh terhadap pengetahuan ibu tentang pencegahan kejang demam berulang. Peneliti meyakini bahwa pengetahuan seseorang tidak hanya dipengaruhi oleh pemberian edukasi saja 
akan tetapi banyak faktor yang bisa memengaruhi pengetahuan seseorang salah satunya adalah tingkat pendidikan. Semakin tinggi tingkat pendidikan seseorang rasa ingin tahunya akan semakin besar sehingga orang tersebut akan berusaha mencari informasi. Dengan tingkat pendidikan yang lebih tinggi mereka juga akan mampu mengakses pengetahuan dengan mudah dan cepat salah satunya dengan menggunakan internet.

Hasil ini sejalan dengan penelitian Hanafi, dkk (2014) yang menunjukkan bahwa hasil uji multivariat logistic regression ada pengaruh karakteristik responden (paritas, cara melahirkan, tingkat pendidikan, status pekerjaan, umur) terhadap pengetahuan, sikap dan ketrampilan ibu dalam penanganan demam pada anak dengan nilai $p<0,05$. Namun hasil penelitian Siriat, Rustina, \& Waluyanti (2013) menunjukkan hasil yang berbeda, hasil uji multivariat karakteristik responden (usia, tingkat pendidikan, penghasilan, jumlah anak dan keterpaparan informasi) pada penelitian ini tidak berpengaruh terhadap pengetahuan, sikap dan ketrampilan orang tua dalam penanganan demam pada anak dengan nilai $(p>0,05)$.

Perbedaan ini kemungkinan disebabkan pada penelitian Siriat, Rustina, \& Waluyanti (2013) rata-rata responden memiliki pendidikan yang sama yaitu SMP dan SMA sedangkan pada penelitian ini tingkat pendidikan responden beragam dari SD sampai Perguruan Tinggi. Hal ini kemungkinan yang meyebabkan tingkat pendidikan tetap berpengaruh terhadap pengetahuan setelah edukasi walaupun telah dikontrol.

\section{DAMPAK EDUKASI KESEHATAN TER- HADAP SIKAP IBU DALAM PENCE- GAHAN KEJANG DEMAM BERULANG}

Pada hasil penelitian ini terdapat perbedaan secara bermakna sikap ibu pada kedua kelompok setelah pemberian edukasi dengan nilai $p=0,001 ;(p<0,05)$. Hal ini menunjukkan bahwa pemberian edukasi kesehatan mempunyai dampak dalam mengubah sikap orang tua ke arah yang positif dalam mencegah kejang demam berulang. Semakin banyak informasi yang didapatkan maka perilaku seseorang terhadap kesehatan akan semakin baik.

Sesuai dengan hasil penelitian Eze, dkk (2015) tentang efek edukasi kesehatan terhadap pengetahuan, sikap dan pertolongan pertama pada epilepsi yang menunjukkan bahwa setelah diberikan pendidikan kesehatan terdapat perubahan sikap seseorang dari negatif ke arah positif sebesar $16,4 \%$, dengan nilai statistik $(p<0,05)$. Hal ini menunjukkan bahwa pendidikan kesehatan secara bermakna dapat merubah sikap seseorang yang memandang epilepsi sebagai sesuatu yang negatif menjadi sesuatu yang lebih positif. Sejalan dengan penelitian Hudayani (2014) yang menunjukkan bahwa pemberian edukasi dan konseling efektif merubah sikap ibu dalam memberikan nutrisi kepada anak dengan ODHA ( $p=0,048 ; p<0,05)$.

Parvez, Wiroonpanich, \& Naphapunsakul (2010) mengatakan pemberian edukasi kesehatan terbukti efektif dalam merubah perilaku ibu dalam merawat anak dengan pneumonia, dengan nilai $p=0,001$ $(p<0,05)$. Hasil penelitian Siriat, Rustina, \& Waluyanti (2013) juga menemukan bahwa pemberian informasi secara bermakna memengaruhi sikap orang tua dalam menangani demam pada anak dengan nilai $(p<0,05)$. Sulistinadewi, Nurhaeni, \& 
Gayatri (2012) juga menemukan bahwa pendidikan kesehatan dapat meningkatkan sikap ibu. Pemberian informasi merupakan faktor yang dapat memengaruhi orang tua dalam menentukan sikap, sehingga mampu mengambil keputusan yang tepat dalam menangani demam pada anak. Informasi merupakan dasar dari pengetahuan, sementara pengetahuan merupakan dasar bagi orang tua dalam menetukan sikap yang tepat dalam mengambil keputusan.

Hasil analisis multivariat dalam penelitian ini menunjukkan ada pengaruh yang signifikan antara pemberian edukasi dengan sikap ibu $(p<0,01)$ setelah dikontrol oleh variabel usia ibu, tingkat pendidikan, penghasilan, keterpaparan informasi, riwayat anak dirawat dan riwayat anak dirawat karena kejang. Hal ini menunjukkan bahwa perubahan sikap ibu ke arah positif tentang pencegahan kejang demam berulang merupakan dampak dari edukasi kesehatan. Namun dalam penelitian ini ditemukan variabel perancu yang tetap memengaruhi sikap walaupun telah dikontrol yaitu tingkat pendidikan dan keterpaparan informasi.

Priyoto (2014) mengatakan pendidikan adalah proses pengubahan pengetahuan, sikap serta perilaku seseorang atau kelompok sebagai upaya mendewasakan manusia melalui upaya pengajaran, pelatihan dan penelitian. Secara teori, semakin tinggi pendidikan seseorang maka semakin baik pengetahuan, sikap dan perilaku yang ia miliki. Hal ini sesuai dengan yang ditemukan peneliti bahwa tingkat pendidikan bisa memengaruhi pengetahuan dan sikap seseorang. Hal ini sesuai dengan hasil penelitian Yabanci \& Karakus (2014) yang menemukan bahwa semakin baik pengetahuan orang tua tentang nutrisi maka semakin baik pula sikap orang tua dalam menyediakan nutrisi untuk anak-anaknya.

\section{SIMPULAN}

Pemberian edukasi kesehatan dapat meningkatkan pengetahuan dan sikap ibu dalam mencegah terjadinya kejang demam berulang. Saran dari hasil penelitian ini adalah edukasi dengan menngunakan media video dapat dimasukkan ke dalam rencana asuhan keperawatan, ketika anak pertama kali dirawat di rumah sakit karena kejang demam, karena terbukti dapat meningkatkan pengetahuan ibu sehingga ibu dapat mengambil sikap yang positif untuk pencegahan terjadinya kejang demam berulang.

\section{DAFTAR PUSTAKA}

Arsyad, A. (2013). Media Pembelajaran. Jakarta: Rajawali Press.

Deliana, M. (2002). Tata laksana kejang demam pada anak. Sari Pediatri, 4 (2), 59-62.

Eze, C. N., Ebuehi, O. M., Brigo, F., Otte, W. M., \& Igwe, S. C. (2015). Effect of health education on trainee teachers' knowledge, attitudes, and first aid management of epilepsy: An interventional study. Seizure, 33: 46-53. https://doi.org/10.1016/j. seizure.2015.10.014

Eskandarifar A, Asadolah F, Gamileh A and Ibrahim G. (2017). The Risk Factors in Children with Simple and Complex Febrile Seizures: An Epidemiological Study. Int J Pediatr, 5(6).

Guttmacher. (2005). Into A New World: Young Women's Sexual and Reproductive. Retrieved from Lives. http://www.agi-usa.org/pubs/new_ world indo.html.

Gueguen, J., Fauvel, G., Luhman, N., \& Bouchon, N. (2010). Health education: A practical guide for health care project. 
Hanafi, M. I., Abdel, S., Shalaby, H., Falatah, N., \& El-ammari, H. (2014). Impact of health education on knowledge of, attitude to and practice of breastfeeding among women attending primary health care centres in Almadinah Almunawwarah, Kingdom of Saudi Arabia: Controlled pre e post study. Journal of Taibah University Medical Sciences, 9(3): 187-193. https://doi. org/10.1016/j.jtumed.2013.11.011.

Hockenberry, M. J. \& Wilson, D. (2009). Wong's essentials of pediatric nursing (8th ed). St Louis, Missouri: Mosby Elsevier.

Hudayani, F. (2014). Pengaruh pemberian edukasi dan konseling gizi terhadap pengetahuan sikap perilaku dan berat badan ODHA di UPT HIV RSUPN Dr. Cipto Mangunkusumo Jakarta (Tesis). Universitas Indonesia, Jakarta, Indonesia.

Kalalang, J. P., Masloman, N. \& Mannoppo, J. I (2016). Profil kejang demam di Bagian ilmu Kesehatan Anak RSUP Prof. Dr. R. D. Kandau Manado. Jurnal e-Clinic (eCl), 4, (2), 51-55.

Kızılay, D. Ö., Kırdök, A. A., Ertan, P., Ayça, S., Demet, M. M., \& Polat, M. (2017). Information is power: An interventional study on parents of children with febrile seizures. Retrieved from https://www. journalagent.com/z4/vi.asp?pdir=jp r\&plng=eng\&un=JPR-43433.

Kyle, T., \& Carman, S. (2017). Essential of pediatric nursing $\left(3^{\text {th }}\right.$ ed). Philadelphia: LippincottWilliams \& Wilkins.

Lee, J.M., Kim, S.J., \& Min, H.Y. (2017). The Effect of smartphone-based nebulizer therapy education on parent's knowledge and confidence of performance in caring for children with respiratory disease, Journal of Pediatric Nursing, 36: 13-19, http://dx.doi.org/10.1016/j. pend.2017.04.012.

Legg, K. T., \& Newton, M. (2017). Counselling adults who experience a first seizure. Seizure, 49: 6468. https://doi.org/10.1016/j. seizure.2016.09.012.

Lenzowski, E., Tung-Hahn, E., Higareda, J., McCormick, C., Markoff, T., Arffa, M., ... Alam, M. (2017). Video education to improve recognition of common benign and malignant cutaneous lesions and skin cancer prevention in the public. International Journal of Women's Dermatology: 4-6. http:// doi.org/10.1016/j.ijwd.2017.10.005.

Maulana, H. D. J. (2009). Promosi Kesehatan. Jakarta: EGC.

Maryati, D. \& Septikasari, M. (2009). Kesehatan reproduksi teori dan praktikum. Yogyakarta: Nuha Medika.

Najimi, A., Dolatabadi, N., Esmaeili, A., \& Sharifirad, G. (2013). The effect of educational program on knowledge, attitude and practice of mothers regarding prevention of febrile seizure in children. Journal of Education and Health Promotion, 2(1): 26. http://dx.doi. org/10.4103/2277-9531.112703.

Notoatmodjo, S. (2005). Promosi Kesehatan Teori dan Aplikasi. Jakarta: Rineka Cipta.

Notoatmodjo S. (2012). Promosi Kesehatan dan Perilaku Kesehatan. Jakarta: Rineka Cipta.

Onji S.H. Hassanpour, M. Ghofrani, N. Taheri D, \& AR Ziaee. (2009). Determining teh Risk Factors of Recurrent to Hazrat-e-Ali Asghar Childrens Hospital. Razi Journal of Mecial Sciences, 16(65). 
Parvez, M., M., Wiroonpanich, W., \& Naphapunsakul, M. (2010). The effects of educational program on child care knowledge and behaviors of mothers of children under five years with pneumonia. Bangladesh Journal of Medical Science, 9(3).

Patel, N., Ram, D., Swiderska, N., Mewasingh, L. D., Newton, R. W., \& Offringa, M. (2015). Febrile seizures. BMJ: British Medical Journal (Online), 351. http://dx.doi. org/10.1136/bmj.h42

Paul, S. P., Rogers, E., Wilkinson, R., \& Paul, B. (2015). Management of febrile convulsion in children. Emergency Nurse (2014), 23(2), 18-25. doi:http://dx.doi.org/10.7748/ en.23.2.18.e1431.

Paul, S. P, Blaikley, S., \& Chinthapalli, R. (2012). Clinical update: Febrile convulsion in childhood. Community Practitioner, 85(7): 36-38. Retrieved from https://search.proquest.com/ docview/1027219982?account id $=17242$.

Priyoto. (2014). Teori sikap dan perilaku dalam kesehatan. Yogyakarta: Nuha Medika.

Santoso H \& Ismail A. 2009. Memahami Krisis Usia Lanjut. Jakarta: Gunung Mulia.

Sadleir, L. G., \& Scheffer, I. E. (2007). Febrile seizures. BMJ: British Medical Journal, 334(7588): 307311. http://dx.doi.org/10.1136/ bmj.39087.691817.AE.
Siriat, N. A. J., Rustina, Y., \& Waluyanti, F. T. (2013). Pemberian informasi meningkatkan pengetahuan, sikap dan ketrampilan orang tua dalam penanganan demam pada anak. Jurnal Keperawatan Indonesia, 16(2): 101-106.

Soundari, E. S., Kokilavani, N., \& Kumar, C. S. (2014). A study to assess the effectiveness of educational intervention on knowledge and attitude of mothers regarding care of children with convulsion disorder at melmaruvathur. Asian Journal of Nursing Education and Research, 4(4): 457-460. Retrieved from https://search.proquest.com/docvie w/1702908679? accountid=17242

Sulistinadewi, N. L. K., Nurhaeni, N., \& Gayatri, D. (2012). Pendidikan kesehatan keluarga efektif meningkatkan kemampuan ibu dalam merawat anak diare. Jurnal keperawatan Indonesia, 15(3): 165170.

Wawan \& Dewi. (2010). Teori \& pengukuran pengetahuan, sikap, dan perilaku manusia. Yogyakarta: Nuha Medika.

Yabanci, N., \& Karakus, S. Ş. (2014). The effects of mother' $s$ nutritional knowledge on attitudes and behaviors of children about nutrition. Procedia - Social and Behavioural Sciences, 116: 4477-4481. https:// doi.org/10.1016 